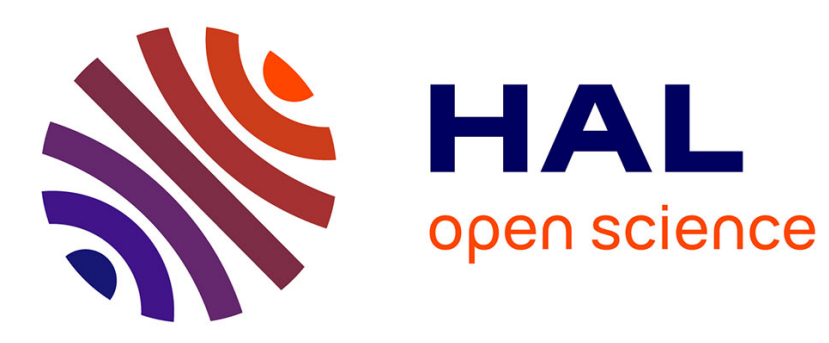

\title{
The impact of expenditure rules on budgetary discipline over the cycle
}

Fédéric Holm-Hadulla, Sebastian Hauptmeier, Philipp Rother

\section{To cite this version:}

Fédéric Holm-Hadulla, Sebastian Hauptmeier, Philipp Rother. The impact of expenditure rules on budgetary discipline over the cycle. Applied Economics, 2011, pp.1. 10.1080/00036846.2011.572855 . hal-00711446

\section{HAL Id: hal-00711446 \\ https://hal.science/hal-00711446}

Submitted on 25 Jun 2012

HAL is a multi-disciplinary open access archive for the deposit and dissemination of scientific research documents, whether they are published or not. The documents may come from teaching and research institutions in France or abroad, or from public or private research centers.
L'archive ouverte pluridisciplinaire HAL, est destinée au dépôt et à la diffusion de documents scientifiques de niveau recherche, publiés ou non, émanant des établissements d'enseignement et de recherche français ou étrangers, des laboratoires publics ou privés. 


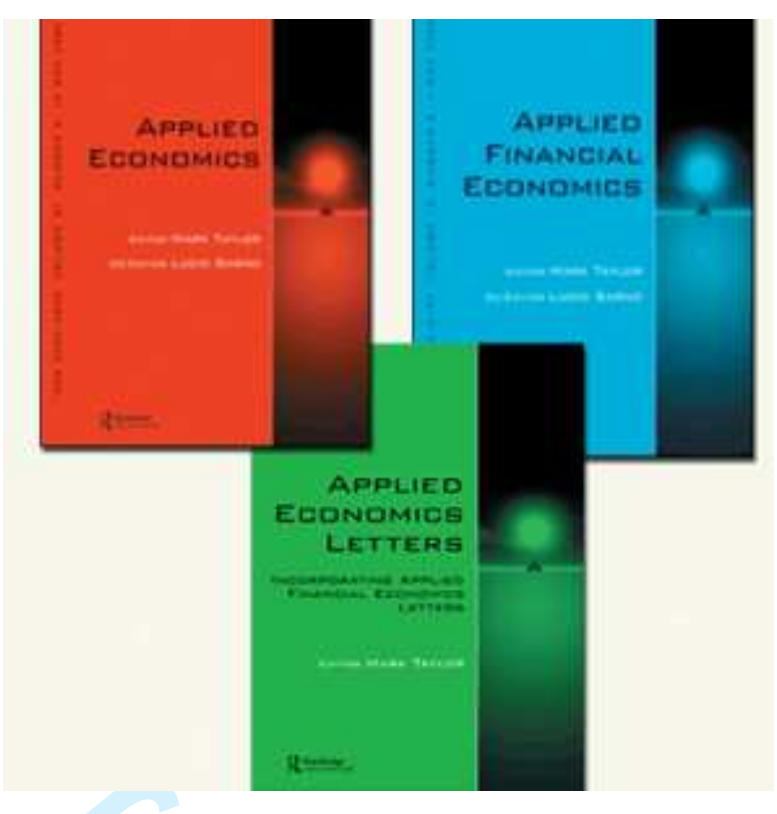

\section{The impact of expenditure rules on budgetary discipline over the cycle}

\begin{tabular}{|r|l|}
\hline Journal: & Applied Economics \\
\hline Manuscript ID: & APE-2009-0369.R1 \\
\hline Journal Selection: & Applied Economics \\
\hline Date Submitted by the \\
Author: & 20 -Dec-2010 \\
\hline Complete List of Authors: & $\begin{array}{l}\text { Holm-Hadulla, Fédéric; European Central Bank, Fiscal Policies } \\
\text { Division } \\
\text { Hauptmeier, Sebastian; European Central Bank, Fiscal Policies } \\
\text { Division } \\
\text { Rother, Philipp; European Central Bank, Fiscal Policies Division }\end{array}$ \\
\hline JEL Code: & $\begin{array}{l}\text { C23 - Models with Panel Data < C2 - Econometric Methods: Single } \\
\text { Equation Models < C - Mathematical and Quantitative Methods, E62 } \\
\text { - Fiscal Policy|Public Expenditures, Investment, and } \\
\text { FinancelTaxation < E6 - Macro Policy Formation, Macro Public } \\
\text { Finance, Macro Policy, etc < E - Macroeconomics and Monetary } \\
\text { Economics, H50 - General < H5 - National Government } \\
\text { Expenditures and Related Policies < H - Public Economics }\end{array}$ \\
\hline Keywords: & \begin{tabular}{l} 
expenditure rules, fiscal discipline, stabilisation, spending bias \\
\hline
\end{tabular} \\
\hline
\end{tabular}




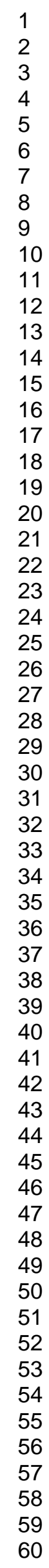

\section{SCHOLARONE ${ }^{m}$ \\ Manuscripts}

7

25

26

27
28

29

30

31

33

34

35

36

37

38

40

41

42

44

45

46

47

48

49

51

52

54

55

57

58

59

60 


\title{
The impact of expenditure rules on budgetary discipline over the cycle*
}

\author{
F. Holm-Hadulla ${ }^{\mathrm{a}, \Delta}$, S. Hauptmeier ${ }^{\mathrm{a}}$ and P. Rother ${ }^{\mathrm{a}}$ \\ ${ }^{a}$ European Central Bank, Directorate General Economics, Fiscal Policies \\ Division, Kaiserstraße 29, D-60311 Frankfurt am Main, Germany.
}

\begin{abstract}
We study the impact of expenditure rules on the propensity for governments to deviate from their expenditure plans in response to surprising cyclical developments. Theoretical considerations suggest that due to political fragmentation in the budgetary process expenditure policy might be prone to a pro-cyclical bias. However, this tendency may be mitigated by strictly enforced expenditure rules. These hypotheses are tested against data from a panel of European Union (EU) Member States. Our key findings are that (i) deviations between actual and planned government expenditure tend to be positively related to output gap surprises, and (ii) expenditure rules reduce this pro-cyclical bias. These results are particularly pronounced when the analysis is confined to spending items with a high degree of budgetary flexibility.
\end{abstract}

\footnotetext{
${ }^{\Delta}$ Corresponding author. E-mail: federic.holm-hadulla@ecb.int.

${ }^{*}$ The views expressed in this article are those of the authors and do not necessarily reflect those of the European Central Bank.
} 


\section{Introduction}

Institutional restrictions to budgetary decision-making are a common feature of fiscal governance in the EU Member States. In particular, in the last two decades, many governments have adopted numerical fiscal rules which set explicit ceilings for key budgetary aggregates (for an overview see Debrun et al., 2008). These rules are mainly motivated as a device to correct coordination failures inherent in the budgetary process: governments typically consist of multiple decision-makers which cater to diverse constituencies and compete for overall fiscal resources available to society. As pointed out by von Hagen and Harden (1995), this arrangement gives rise to a common pool problem leading to inefficiently high levels of government expenditure. Moreover, it may induce a pro-cyclical spending bias since pressures for budgetary expansion tend to intensify in upturns whereas in downturns governments may be forced to make up for past fiscal profligacy. ${ }^{1}$ This provides a possible explanation for the positive relation between public spending and the cyclical position of the economy found in several empirical studies (for evidence on OECD countries see Lane, 2003; on developing countries see Kaminsky et al., 2004; on EU countries see Turrini, 2008).

Against this background, a widespread consensus on the beneficial role of rules to restrict government expenditure has emerged, which is summarized by the European Commission's assessment that: 'Enforced national expenditure rules (...) help to counteract forces leading to pro-cyclical fiscal policy in good times and thus prevent the need to retrench in bad times' (European Commission,

\footnotetext{
${ }^{1}$ For models establishing a formal link between the common pool problem in budgetary processes and fiscal pro-cyclicality see Tornell and Lane (1999) and Talvi and Végh (2005).
} 
2004). Yet, while several recent studies examine the link between fiscal rules and expenditure policies in a broader context, empirical evidence for their impact on the cyclicality of government spending is scant. ${ }^{2}$ One of the few analyses addressing this issue directly is provided by Turrini (2008) who finds that the pro-cyclical spending bias was less pronounced in those EU countries with strong expenditure rules.

The aim of the current article is to further explore the effect of expenditure rules on the cyclical stance of government expenditure in the EU Member States. In particular, we test whether governments tend to deviate from previously formulated expenditure targets in response to surprising cyclical developments and whether this reaction differs in countries with weak and strong expenditure rules. The specific focus on deviations between actual and planned government expenditure is motivated by two stylized facts (see Beetsma et al., 2009). First, fiscal performance in the European Union has primarily suffered from a failure to implement budgetary plans rather than a lack of ambition in formulating them: while Member States typically set out targets in their stability and convergence programmes that would lead to an improvement in budget balances, these adjustment plans tend to be overcompensated by implementation failures thus resulting in a deterioration in fiscal positions. Second, budgetary slippages mainly originate from the spending side with governments systematically

\footnotetext{
${ }^{2}$ Focussing on the overall size of public spending, Debrun et al. (2008) find that those EU countries with strong expenditure rules tend to have slightly lower primary expenditure-to-GDP ratios. Badinger (2009) finds that after the introduction of fiscal rules in several OECD countries since the 1990s, the volatility of government spending has fallen significantly in these countries. For a sample of $15 \mathrm{EU}$ countries Wierts (2008) finds that government spending tends to be less responsive to revenue windfalls or shortfalls in countries with stringent expenditure rules. By contrast, Büttner and Wildasin (2009), find that the presence of formal borrowing restrictions for US municipalities intensifies fluctuations in investment spending in response to revenue shocks.
} 
exceeding the planned expenditure paths set out in their respective programmes. ${ }^{3}$ Against this background, analyses of deviations between actual and planned government spending yield important insight into the determinants of fiscal performance in the European Union.

Besides studying broad aggregates of government spending, the analysis also distinguishes between discretionary and nondiscretionary items of government expenditure. This distinction seems important since aggregate government expenditure typically includes items (such as interest expenditure or certain legally mandated transfers), that can barely be adjusted by policymakers in the short-run, even if they had an incentive to do so. At the same time, theoretical predictions concerning the impact of fiscal rules on fiscal cyclicality presuppose that government spending can react spontaneously to exogenous shocks. Hence, studying overall expenditure may partly conceal policy responses in discretionary spending since expenditure items with low budgetary flexibility hamper statistical inference.

The article is organized as follows. Section II describes the construction of variables and presents the econometric model. Section III reports regression results. Section IV discusses policy implications and concludes.

\section{Empirical Strategy}

\section{Dependent Variables}

Our aim is to capture the discrepancy between governments' actual expenditure policy for a given period and their previously formulated expenditure plans. We

\footnotetext{
${ }^{3}$ Actual revenues tend to be slightly above the levels targeted in the programmes thus exerting a positive impact on budget balances.
} 
obtain the latter from the EU Member States' stability and convergence programmes which we interpret as the governments' fiscal stance ex ante, i.e. before surprises in macroeconomic conditions take place. Accordingly, we define the dependent variable as

$$
d e v_{i, t}^{k}=g_{i, t}^{k}-\tilde{g}_{i, t}^{k},
$$

where $g_{i, t}^{k}$ measures the actual outcome for general government expenditure as a ratio of nominal Gross Domestic Product (GDP) in country $i$ and year $t$ as reported in the European Commission's Ameco Database. $\tilde{g}_{i, t}^{k}$ is the corresponding target for the expenditure ratio for year $t$ as formulated in the country's stability or convergence programme published in year $t-1$. To focus on those deviations between $g_{i, t}^{k}$ and $\tilde{g}_{i, t}^{k}$ that derive from changes in expenditure policy rather than differences in denominators we express both variables as a percentage of actual nominal GDP. ${ }^{4}$

In a second step, we use disaggregated information on government expenditure to distinguish between expenditure items which are readily manipulated by policy-makers (i.e. discretionary) and those which are, in the short-run, exogenous from the government's perspective (i.e. nondiscretionary). While already conceptually this differentiation is not clear-cut, it is further inhibited by the aggregation level and reporting conventions in the stability and convergence

\footnotetext{
${ }^{4}$ While stability and convergence programmes contain growth rate forecasts, they do not always provide the information needed to derive the GDP forecast in levels. Hence, we use the respective Commission forecast to adjust denominators and control for differences between stability and convergence programme and Commission growth rate forecasts in the empirical analysis (see Section III).
} 
programmes. $^{5}$ In particular, the categories collective consumption and other expenditure reported in the programmes lump together various spending items which may not be disentangled based on the available information. ${ }^{6}$ As regards social transfers, reporting practices differ substantially across countries and time thus impeding interpretability of this variable. ${ }^{7}$ These qualifications prevent an exhaustive classification of government spending items as either discretionary or nondiscretionary. Instead, the analysis focuses on the remaining expenditure items treating them as polar cases with respect to their budgetary flexibility. In line with related literature, interest expenditure is classified as nondiscretionary since the outstanding amount of government debt mostly results from past rather than current policy choices and interest rates are determined on capital markets rather than being a choice variable of governments (see, e.g. Blanchard, 1990; Larch and Salto, 2005). Discretionary spending is defined as the sum of subsidies and gross fixed capital formation both of which are more easily adjusted in the short run (e.g. via changes in the implementation schedules of existing spending programmes). Deviations in discretionary and in nondiscretionary spending are also expressed in percent of actual nominal GDP. ${ }^{8}$

\footnotetext{
${ }^{5}$ Since 2001, EU Member States have been required to provide detailed projections in their stability and convergence programmes for collective consumption, social transfers in kind, social transfers other than in kind, interest payments, subsidies, gross fixed capital formation, and other expenditure.

${ }^{6}$ Most notably, the variable collective consumption typically includes compensation of employees and intermediate consumption. Given the transaction cost associated with changes in the public workforce and the elaborate negotiation processes surrounding public sector wage setting, the flexibility for compensation of employees to respond to surprises in cyclical conditions appears limited. By contrast, intermediate consumption which includes a broad range of operating expenses leaves significantly more scope for adjustments at the margin.

${ }^{7}$ For example, Germany only reports social transfers other than in kind as a separate variable whereas social transfers in kind is generally reported along with collective consumption. By contrast, in some years the French stability programmes only report total social transfers. ${ }^{8}$ For an alternative approach to isolating the discretionary aspect of fiscal policy based on statistical properties of time-series see Badinger (2009) and Afonso et al. (2010).
} 
In light of the related literature, the interpretation of stability and convergence programmes as a government's fiscal plans merits discussion. As pointed out by several commentators, Member States might use these programmes as a strategic device, e.g. to signal to the European authorities that they intend to meet their obligations under the Stability and Growth Pact (Strauch et al., 2004; von Hagen, 2010). Hence, the reported fiscal paths for future periods might deviate from those which governments consider feasible based on internal projections. However, while this concern applies to the medium-term projections in the programmes (usually covering a time horizon of up to three years) we only use the projections referring to the next year; these figures are in most cases equivalent to the budgets approved by national parliaments. Thus, in contrast to projections over a longer time horizon, they embed a direct political commitment and may thus be interpreted as the government's planned fiscal stance.

Table 1 displays summary statistics for the variables used in the empirical analysis. While all EU Member States have been required to report detailed spending plans in their stability or convergence programmes since 2001, some deficiencies in reporting practices and lack of data availability regarding some explanatory variables reduces the sample to 145 observations over the period 2002 to 2008 (see below). ${ }^{9}$ While all expenditure variables except for interest spending tend to exceed their planned levels, the figures are subject to large variation so that no clear patterns can be inferred.

\footnotetext{
${ }^{9}$ Belgium, Malta, and France do not report sufficiently disaggregated spending plans in the 2001 vintage, the 2005 vintage, and 2001-2004 programme vintages, respectively, to compute discretionary spending deviations thus reducing the sample size for this variable by six observations. Since Spain only reports gross fixed capital formation in the 2001-2005 stability programme vintages we use this variable exclusively to compute the discretionary spending deviations. Since expenditure plans for Bulgaria and Romania are only available starting in 2007 they are not considered in the analysis.
} 


\section{[TABLE 1]}

\section{Main Explanatory Variables}

In line with related literature, we use the gap between actual and trend GDP as a measure for the cyclical position of the economy. Since we are interested in surprising developments in the cyclical position, again, we include this variable in terms of deviations between projected and actual levels. To be specific, we seek to capture the discrepancies between the actual cyclical position of the economy in year $t$ and the cyclical position that governments expected for year $t$ at the time when they produced their fiscal forecast in year $t-1$. Hence, a potential proxy for the governments' expectations on cyclical developments has to meet two requirements: first, it should derive from an official source which governments are likely to perceive as a benchmark for their own projections. Second, it should be up-to-date, i.e. the time span between the release of the output gap forecast and the preparation of the stability and convergence programmes should be sufficiently short. Both conditions are likely to be met by the European Commission's autumn forecast; given that it is typically released in the third quarter of the year and provides a timely measure for the outlook on future economic conditions which prevails at the time when the stability and convergence programme projections are finalized. Accordingly, the explanatory variable for output gap surprises $O G_{i, t}$ is defined as the difference between the actual output gap in period $t$ and the European Commission's output gap forecast from period $t-1$ for period $t$. To align the denominator with that of the 
dependent variable, this difference is also expressed as a percentage of actual nominal GDP.

To capture the extent to which national expenditure policy faces domestic institutional constraints, we use the expenditure rules index as developed by Debrun et al. (2008). This index is based on a survey conducted by the Working Group on the Quality of Public Finances among practitioners and researchers in the field of fiscal policy. It includes all budgetary provisions which fix numerical targets or ceilings for government expenditure. To attach weights to different institutions, the index takes into account both the share of overall public spending covered by the rule and qualitative features such as the type of enforcement mechanisms and media visibility. As pointed out by Inman (1998), the actual enforcement of rules is particularly important to capture the extent to which fiscal policy is really restricted by the institutional framework. Taken together, this measure bears strong appeal for empirical implementation as it translates a broad set of institutional provisions into a country-specific cardinal ranking. ${ }^{10}$

Theoretical considerations point to two different channels through which expenditure rules might mitigate pro-cyclical spending bias: first, if rules are binding in that both a marginal increase in public spending leads to noncompliance and non-compliance is associated with political or legal sanctions, they provide a direct incentive for fiscal discipline. This favourable impact on budgetary discipline in turn should be expected to prevent the need for fiscal

\footnotetext{
${ }^{10}$ For a detailed description of the computation of this index see European Commission (2006) and Debrun et al. (2008). The index is normalized to have a zero mean and unit variance. It also displays some time-variability, especially in the 1990's. However, for the time-period considered in this study the index only varies across countries but not across time, except for a single increase in the expenditure rule index in Italy in 2004 and in France in 2005.
} 
tightening in response to unfavourable economic developments. Second, as pointed out by Schuknecht (2004), numerical fiscal rules may induce budgetary discipline indirectly, in that they serve as benchmarks against which imperfectly informed electorates evaluate governments' fiscal performance. Hence, in the presence of strong numerical rules expenditure policy should be more consistent with budgetary targets and less prone to pro-cyclical reactions even if they do not bind in a strict sense.

\section{Econometric Model}

To analyze the impact of expenditure rules on budgetary discipline over the cycle, we estimate the following equation:

$$
d e v_{i, t}^{k}=c_{i}+d_{t}+\alpha O G_{i, t}+\beta\left(O G_{i, t} \times E R_{i}\right)+\gamma X_{i, t}+u_{i, t}^{k}
$$

where $d e v_{i, t}^{k}$ refers to deviations between actual and planned levels of spending with respect to spending category $k$ (i.e. total, primary, discretionary, or interest) for country $i$ in period $t ; O G_{i, t}$ is the output gap surprise; $E R_{i}$ is a countryspecific vector which indicates the strength of national expenditure rules; $O G_{i, t} \times E R_{i}$ is an interaction term between output gap surprises and the expenditure rules index. $d_{t}$ and $c_{i}$ are full sets of time and country fixed effects, respectively; $X_{i, t}$ is a matrix containing time and country-specific control variables and $u_{i, t}^{k}$ is a random error term. ${ }^{11}$

\footnotetext{
${ }^{11}$ Note that since the expenditure rules index is almost perfectly collinear with the fixed effects (see footnote 9), it is not included in the regression equation.
} 
Since government expenditure is an important component of aggregate demand simultaneity problems might arise with respect to variables measuring cyclical conditions. To address the resulting identification problem we exploit the 'structural' part of the output gap surprises for causal inference: forecast errors may arise from unexpected developments in actual and/or in trend GDP. Since the latter is essentially unaffected by short-run fluctuations in the time series for GDP, it may also be treated as exogenous to those fluctuations caused by changes in government spending. ${ }^{12}$ Thus, we instrument the output gap surprise variable with the forecast error in trend GDP. We extend the instrument set by the GDP-weighted average of output gaps in all foreign sample countries to capture international cyclical developments, not directly affected by domestic expenditure policy (Galí and Perotti, 2003). While the exogeneity assumption for this variable, a priori, appears less compelling than for the forecast error in trend GDP, the number of instruments allows us to test the validity of the instrument set using over-identifying restrictions.

Another potential source of endogeneity originates from the expenditure rules index. Fiscal institutions can not generally be regarded as exogenous since both the propensity to implement certain restrictions and overall fiscal performance may be correlated with unobservable country-specific preferences (for a discussion see Poterba, 1996 and Inman, 1998). Moreover, the self-commitment implied in effective numerical fiscal rules provides an incentive for governments with higher ability or willingness for achieving fiscal targets to implement stricter fiscal rules (see Debrun and Kumar, 2007). However, since the

\footnotetext{
${ }^{12}$ The European Commission computes trend GDP based on a Hodrick-Prescott filter; in general, trend values derived by this method tend to be strongly influenced by actual values at the end of the sample. However, the Commission's methodology corrects for the end point bias, thus supporting our identification strategy; see Röger and Ongena (1999).
} 
expenditure rules index displays almost no variation over the time dimension of the sample and the regression includes fixed effects, the bias from potential correlation with latent country-specific preferences is mitigated. Furthermore, simultaneity bias is unlikely to impair our results due to the short time dimension of our panel: the type of institutional restrictions considered in the expenditure rules index are, by definition, permanent constraints on fiscal policy. In most cases, these constraints are integrated into a multi-annual budgetary framework and/or based on legal, constitutional, or long term political commitments which are not readily adjusted to accommodate current fiscal developments. As pointed out by Alesina and Perotti (1996), they may thus be considered exogenous in the short- and medium-term.

The set of control variables includes the lagged stock of government debt and in some specifications the lagged fiscal balance to reflect the possibility that the overall fiscal position may influence the extent to which external fiscal surveillance and the financial markets force governments to comply with their expenditure targets. To allow for systematic differences in budgetary decisionmaking across countries with large and small public sectors lagged values of the expenditure or revenue ratio are included. In several specifications, we augment the model with a dummy which equals one in years of parliamentary elections and zero otherwise to take into account that upcoming elections may reinforce the incentive to 'buy political support'. Finally, in several specifications we explicitly control for inflation rates as they may affect government expenditure and nominal GDP differently thus giving rise to a 'mechanical correlation' between output gap surprises and the denominator of the dependent variables. 
Descriptive statistics on these control variables are shown in the bottom part of Table 1.

\section{Results}

Table 2 reports baseline regression results. The positive coefficient on the output gap surprise in column 1 points to pro-cyclical slippages in total government expenditure. To be specific, an output gap surprise of one percentage point goes along with a deviation between spending outcomes and plans of close to half a percentage point in the same direction when the expenditure rules index is at its sample mean. At the same time, the negative coefficient for the interaction term indicates that this pro-cyclical pattern is less pronounced in countries with strong expenditure rules. In particular, an increase in the expenditure rules index by one standard deviation reduces the pro-cyclical deviation in government expenditure by almost two thirds. Qualitatively similar results are obtained when analyzing primary and discretionary expenditure (see columns 2 and 3). However, the precision of estimates differs notably across specifications. While in the case of total expenditure, coefficients for the output gap surprise and the interaction term are statistically significant at a $10 \%$ significance level only, for primary expenditure the null hypotheses is rejected at a 5\% level and significance rises further when studying discretionary expenditure. ${ }^{13}$

\footnotetext{
${ }^{13}$ Throughout the analysis, the relevant specification tests support our identification strategy. Based on the Sargan/Hansen statistic, the instrumental variables pass the overidentification test. The null hypothesis of weak instruments is clearly rejected. Finally, in many specifications we can not reject the null hypothesis that output gap surprises are endogenous or the p-values of the corresponding test statistic are only slightly above $10 \%$ thus suggesting the use of instrumental variable estimation.
} 
These patterns are in line with the considerations presented in Section II: the fewer spending items with a low degree of budgetary flexibility are considered in the dependent variable, the more salient is the pro-cyclical response of government expenditure. A natural robustness check for this hypothesis is to repeat these exercises using nondiscretionary spending components, exclusively. As expected, output gap surprises do not exert a significant influence on deviations in interest expenditure from targets (see column 4). These results illustrate the importance to differentiate between expenditure items based on their budgetary flexibility when testing the spending bias hypothesis.

Interestingly, the lagged level of debt has a significant positive impact on slippages in total, primary and discretionary spending. An immediate interpretation to this finding is that accumulation of debt and the propensity to miss budgetary targets are driven by common unobservable factors. However, since the identification of causal effects of debt levels on expenditure policy is not at the centre of our attention we do not further investigate this issue. The lagged expenditure level does not affect the tendency for deviations between outcomes and plans. ${ }^{14}$

\section{[TABLE 2]}

Given the nonresponsive nature of interest spending, we focus on primary and discretionary spending in the remainder. In the specification shown in columns 1

\footnotetext{
${ }^{14}$ Several robustness checks of the baseline specification were conducted. For example, we included the lagged spending item under consideration (i.e. lagged primary, discretionary or interest spending) to allow for the possibility that the ambition of fiscal plans depends on the initial size of the respective budgetary aggregate. Moreover, we explicitly controlled for factors giving rise to a "denominator effect" as described in Section II. To this end, we added inflation and the difference between the nominal GDP growth forecast from period t 1 by the European Commission and the one reported in the stability and convergence programmes as additional regressors. Our main results are unaffected by these variations in the basic model. Results for the robustness checks are available upon request.
} 
and 2 of Table 3, we augment the basic model by a dummy variable for parliamentary elections. Consistent with related literature, the notion of politically motivated fiscal profligacy finds some support in our analysis: ${ }^{15}$ countries on average record significant positive primary expenditure overruns in election years. However, no such effect is detected for discretionary spending deviations.

\section{[TABLE 3]}

Economic intuition suggests that the spending bias may occur asymmetrically over the cycle: while pressures for extra spending in good times directly derive from the political economy of the budget process, pro-cyclical tightening in bad times results from the need to make up for this spending profligacy and to ensure fiscal sustainability. However, given that none of the countries studied here faced acute sustainability concerns over the sample period, this secondary effect might be limited. Much rather, the spending bias may give rise to pro-cyclical fiscal expansions which are then not compensated for in downturns (for a discussion see Kolluri and Wahab, 2007). To test this intuition, we modify the baseline specification by allowing the coefficients on $O G_{i, t}$ and $O G_{i, t} \times E R_{i}$ to differ depending on whether output gap surprises take place at positive or negative values of the output gap (see columns 3 and 4 in Table 3). The results support the notion of asymmetric reactions in good and bad times: for both primary and

\footnotetext{
${ }^{15}$ For example, Buti and van den Noord (2004), Cimadomo (2008) and Afonso and Hauptmeier (2009) find for EMU and OECD countries, respectively, that governments tend to adopt a looser fiscal stance in election years. Focussing on tax policy, Andrikopolous et al. (2006) do not find evidence for an electoral cycle which is consistent with the commonly held perception that political pressures for budgetary expansion are mainly focussed on the expenditure rather than the revenue side. Interestingly, for the case of the German regional governments (Länder) Jochimsen and Nuscheler (2010) find the opposite pattern with the increase in debt being lower in preelection years. The authors interpret this finding as reflecting German voters' preferences for fiscal prudence.
} 
discretionary spending the coefficient on the output gap surprise shows the expected sign and is statistically significant in case of a positive output gap. At the same time, the size of the effect is somewhat stronger than in the specifications that do not account for asymmetries. However, we do not observe a statistically significant effect of surprises in the cyclical position if the output gap takes negative values. As regards the impact of expenditure rules, the results give a mixed picture. In the case of discretionary spending, the hypothesis that expenditure rules curb the risk of pro-cyclical spending overruns is confirmed. By contrast, no statistically significant effect is found for the corresponding coefficient in the specification for primary spending. However, these results should be interpreted with caution in view of potential weak identification problems resulting from the fact that in this specification, four (rather than two) endogenous variables had to be instrumented.

As a final exercise, we return to the baseline specification and study how the overall cyclical response of spending varies over the range of the expenditure rules index. Since the coefficients on the output gap surprise variable and the interaction term have opposite signs, the pro-cyclical spending bias found at the sample mean of the expenditure rules index may in fact disappear when it takes on higher values. ${ }^{16}$ The solid lines in Fig. 1 show how the spending response to output gap surprises changes with the expenditure rules index, controlling for all other variables included in the baseline specification (see Table 2); the dashed lines show the $95 \%$ confidence interval around the estimates. As illustrated by the upper panel, a pro-cyclical bias in primary government spending can be

\footnotetext{
${ }^{16}$ Recall that the overall effect of a marginal change in the output gap surprise is $\partial \mathrm{dev} / \partial O G=\alpha+\beta E R$ and thus depends on the coefficient on the interaction term and the value of the expenditure rules index.
} 
observed for a wide range of values for the expenditure rules index. ${ }^{17}$ However, from a value of around 1.05 upwards, the effect ceases to be statistically different from zero (as indicated by the intersection of the lower bound of the $95 \%$ confidence interval and the x-axis). More intuitively, the estimates suggest that countries imitating the expenditure rules that are in place in the Czech Republic, Luxembourg, the Netherlands or Sweden (all of which score above 1.05 on the expenditure rules index) would overcome the tendency for pro-cyclical spending slippages. By contrast, for discretionary expenditure a statistically significant (albeit small) pro-cyclical bias would be expected even in the Netherlands where the expenditure rules index takes the maximum value of 2.27 (see Fig. 1, lower panel).

\section{[Figure 1]}

\section{Conclusion}

This paper analyzes how numerical expenditure rules shape the response of government spending to unexpected changes in macroeconomic conditions. We find that government spending reacts pro-cyclically to surprises in the output gap and that strong domestic expenditure rules serve to mitigate this tendency. Furthermore, the analysis suggests that these findings depend on the type of government expenditure considered in the analysis: while the pro-cyclical bias is particularly pronounced for spending items with a high degree of budgetary flexibility, no cyclical patterns are detected for (largely nondiscretionary) interest expenditure.

${ }^{17}$ The charts are constructed according to the methodology suggested by Brambor et al. (2006). 
The conclusion that institutional restrictions to government expenditure may improve spending discipline has relevant implications for the ongoing debate on options to strengthen fiscal surveillance in EMU. For example, the European Commission's proposal to strengthen the Stability and Growth Pact foresees that government expenditure developments be 'consistent with prudent fiscal policy making' and linked to a 'prudent medium term rate of growth of GDP' (European Commission, 2010). This paper suggests that governments could enhance compliance with such requirements at the European level by enforcing the corresponding expenditure path through effective national expenditure rules. 


\section{Acknowledgements}

We are grateful to Antonio Afonso, Thiess Büttner, Cristina Checherita, Jacopo Cimadomo, Geert Langenus, Philipp Mohl, Christiane Nickel, Ad van Riet, Jürgen von Hagen, Peter Wierts, participants of the ESCB Working Group on Public Finance 2009 Workshop in Cyprus, and an anonymous referee for useful comments. 


\section{References}

Afonso, A., Agnello, L., and Furceri, D. (2010) Fiscal policy responsiveness, persistence and discretion, Public Choice, 145, 503-530.

Afonso, A. and Hauptmeier, S. (2009) Fiscal behaviour in the European Union: rules, fiscal decentralization and government indebtedness, ECB Working Paper No. 1054.

Alesina, A. and Perotti, R. (1996) Fiscal discipline and the budget process, American Economic Review, Papers and Proceedings, 86, 401-407.

Andrikopoulos, A., Loizides, I. and Prodromidis, K. (2006) Taxation and political business cycles in EU economies, Applied Economics, 38, 17611774.

Badinger, H. (2009) Fiscal rules, discretionary fiscal policy and macroeconomic stability: an empirical assessment of OECD countries, Applied Economics, 41, 829-847.

Beetsma, R., Giuliodori, M. and Wierts, P. (2009) Planning to Cheat: EU fiscal policy in real time, Economic Policy, 24, 753-804.

Blanchard, O. J. (1990) Suggestions for a new set of fiscal indicators, OECD Economics Department Working Paper No. 79.

Brambor, T., Clark, W. and Golder, M. (2006) Understanding interaction models: improving empirical analysis, Political Analysis, 14, 63-82.

Buti, M. and Van den Noord, P. (2004) Fiscal policy in EMU: rules, discretion and political incentives, European Commission Economic Paper No. 206.

Büttner, T. and Wildasin, D. (2009) Public investment, revenue shocks and borrowing restrictions, mimeo, Ludwig-Maximilians-University, Munich.

Cimadomo, J. (2008) Fiscal policy in real time, ECB Working Paper No. 919. 
Debrun, X. and Kumar, M. (2007) The discipline-enhancing role of fiscal institutions: theory and empirical evidence, IMF Working Paper No. 171.

Debrun, X., Moulin, L., Turrini, A., Ayuso-i-Casals, J. and Kumar, M. (2008) Tied to the mast? National fiscal rules in the European Union, Economic Policy, 23, 297-362.

European Commission (2004) Quarterly Report on the Euro Area, October Issue, Brussels.

European Commission (2006) Public Finances in EMU, Brussels.

European Commission (2010) Proposal for a regulation of the European Parliament and of the Council amending Regulation (EC) No 1466/97, Brussels.

Galí, J. and Perotti, R. (2003) Fiscal Policy and monetary integration in Europe, Economic Policy, 18, 533-572.

Inman, R. (1998) Do balanced budget rules work? US experience and possible Lessons for the EMU, NBER Working Paper No. 5838.

Jochimsen, B. and Nuscheler, R. (2010) The political economy of the German Länder deficits: weak governments meet strong finance ministers, Applied Economics, 1-17.

Kaminsky, G., Reinhart C. and Végh, C. (2004) When it rains, it pours: procyclical capital flows and macroeconomic policies, NBER Macroeconomics Annual, 19, 11-53.

Kolluri, B. and Wahab, M. (2007) Asymmetries in the conditional relation of government expenditure and economic growth, Applied Economics, 39, 23032322. 
Lane, P. R. (2003) The cyclical behaviour of fiscal policy: evidence from the OECD, Journal of Public Economics, 87, 2661-2675.

Larch, M. and Salto, M. (2005) Fiscal rules, inertia, and discretionary fiscal policy, Applied Economics, 37, 1135-1146.

Poterba, J. (1996) Budget institutions and fiscal policy in the US states, American Economic Review, Papers and Proceedings, 86, 395-400.

Röger, W. and Ongena, H. (1999) The Commission services' cyclical adjustment method, in Indicators of Structural Budget Balances, Banca d'Italia.

Schuknecht, L. (2004) EU fiscal rules: issues and lessons from political economy, ECB Working Paper No. 421.

Strauch, R., Hallerberg, M., and von Hagen, J. (2004) Budgetary forecasts in Europe - the track record of stability and convergence programmes, ECB Working Paper No. 307.

Talvi, E. and Végh, C. A. (2005) Tax base variability and procyclical fiscal policy in developing countries, Journal of Development Economics, 78, 156190.

Tornell, A. and Lane, P. R. (1999) The voracity effect, American Economic Review, 89, 22-46.

Turrini, A. (2008) Fiscal policy and the cycle in the Euro Area: the role of government revenue and expenditure, European Commission Economic Paper No. 323.

von Hagen, J. (2010) Sticking to fiscal plans: the role of institutions, Public Choice, 144, 487-503.

von Hagen, J. and Harden, I. J. (1995) Budget processes and commitment to fiscal discipline, European Economic Review, 39, 771-779. 
Wierts, P. (2008). "How do expenditure rules affect fiscal behaviour?”, DNB Working Paper No. 166. 
Table 1: Descriptive Statistics

\begin{tabular}{lccccc}
\hline & $\mathrm{N}$ & Mean & SD & Min. & Max. \\
\hline Dependent variables & & & & & \\
Deviation Total Expenditure & 145 & 1.07 & 1.75 & -7.03 & 6.39 \\
Deviation Primary Expenditure & 145 & 1.12 & 1.73 & -6.80 & 6.28 \\
Deviation Discretionary Expenditure & 139 & 0.09 & 0.68 & -2.22 & 2.75 \\
Deviation Interest Expenditure & 145 & -0.54 & 0.28 & -0.69 & 1.32 \\
Explanatory variables & & & & & \\
Output Gap Surprise & 145 & 0.71 & 1.25 & -2.88 & 5.43 \\
Expenditure Rules Index & 145 & 0 & 1 & -0.79 & 2.27 \\
Debt Ratio & 145 & 50.33 & 26.62 & 3.49 & 106.89 \\
Expenditure Ratio & 145 & 45.04 & 5.90 & 33.34 & 56.95 \\
Revenue Ratio & 145 & 43.89 & 6.29 & 32.04 & 57.69 \\
Budget balance ratio & 145 & -1.14 & 2.73 & -9.32 & 5.33 \\
GDP deflator & 145 & 3.63 & 3.28 & -0.72 & 23.81 \\
\hline Souces: Europan Combs
\end{tabular}

Sources: European Commission Ameco Database and stability and convergence programmes for fiscal variables; Debrun et al. (2008) for expenditure rules index.

Note: all variables except for GDP deflator and expenditure rules index are expressed in \% of GDP. GDP deflator is measured in terms of percentage change on preceding year. 
Table 2: Baseline regression results

\begin{tabular}{|c|c|c|c|c|}
\hline & $(1)$ & $(2)$ & (3) & $(4)$ \\
\hline & $\begin{array}{l}\text { Deviation } \\
\quad \text { Total } \\
\text { Expenditure }\end{array}$ & $\begin{array}{l}\text { Deviation } \\
\text { Primary } \\
\text { Expenditure }\end{array}$ & $\begin{array}{l}\text { Deviation } \\
\text { Discretionary } \\
\text { Expenditure }\end{array}$ & $\begin{array}{l}\text { Deviation } \\
\text { Interest } \\
\text { Expenditure }\end{array}$ \\
\hline \multirow[t]{2}{*}{ Output Gap Surprise (OGS) } & $0.441 *$ & $0.472 * *$ & $0.343 * * *$ & -0.029 \\
\hline & $(0.241)$ & $(0.240)$ & $(0.078)$ & $(0.034)$ \\
\hline \multirow[t]{2}{*}{$(O G S) *($ Expenditure Rules Index $)$} & $-0.279 *$ & $-0.313 * *$ & $-0.107 * *$ & 0.024 \\
\hline & $(0.165)$ & $(0.160)$ & $(0.042)$ & $(0.016)$ \\
\hline \multirow[t]{2}{*}{ Government Debt (first lag) } & $0.071 * *$ & $0.086 * * *$ & $0.022 *$ & $-0.015 * * *$ \\
\hline & $(0.030)$ & $(0.029)$ & $(0.012)$ & $(0.005)$ \\
\hline \multirow[t]{2}{*}{ Total Government Spending (first lag) } & -0.047 & -0.035 & 0.008 & -0.014 \\
\hline & $(0.109)$ & $(0.107)$ & $(0.043)$ & $(0.020)$ \\
\hline Observations & 145 & 145 & 139 & 145 \\
\hline $\begin{array}{l}\text { Sargan/Hansen test of overidentifying } \\
\text { restrictions ( } p \text {-value) }\end{array}$ & 0.43 & 0.69 & 0.94 & 0.05 \\
\hline $\begin{array}{l}\text { Difference in Sargan/Hansen test for } \\
\text { endogenous regressor (p-value) }\end{array}$ & 0.13 & 0.10 & 0.45 & 0.56 \\
\hline Kleinbergen-Paap rk Wald F-Statistic & 32.93 & 32.93 & 34.56 & 32.93 \\
\hline
\end{tabular}

Notes: All estimates are obtained from two-stage least squares estimation including country- and time-fixed effects. Excluded instruments for the output gap surprise and its interaction with the expenditure rules index are the forecast error in trend GDP, the average output gap in all other countries in the sample and the corresponding interaction terms. Robust standard errors in parentheses. *** significant at $1 \%$ level, ** significant at $5 \%$ level, * significant at $10 \%$ level. Critical value of Stock-Yogo weak identification test for 5\% maximal IV relative bias: 11.04 and 10\% maximal distortion of Wald test: 16.87 . 
Table 3: Impact of parliamentary elections and asymmetries in good and bad times

\begin{tabular}{|c|c|c|c|c|}
\hline & $(1)$ & $(2)$ & (3) & (4) \\
\hline & $\begin{array}{l}\text { Deviation } \\
\text { Primary } \\
\text { Expenditure }\end{array}$ & $\begin{array}{c}\text { Deviation } \\
\text { Discretionary } \\
\text { Expenditure }\end{array}$ & $\begin{array}{l}\text { Deviation } \\
\text { Primary } \\
\text { Expenditure }\end{array}$ & $\begin{array}{c}\text { Deviation } \\
\text { Discretionary } \\
\text { Expenditure }\end{array}$ \\
\hline Output Gap Surprise (OGS) & $\begin{array}{c}0.459 * * \\
(0.239)\end{array}$ & $\begin{array}{c}0.345 * * * \\
(0.077)\end{array}$ & & \\
\hline$(O G S) *($ Expenditure Rules Index $)$ & $\begin{array}{l}-0.285^{*} \\
(0.170)\end{array}$ & $\begin{array}{c}-0.098 * * \\
(0.041)\end{array}$ & & \\
\hline Government Debt (first lag) & $\begin{array}{c}0.095 * * * \\
(0.030)\end{array}$ & $\begin{array}{l}0.023 * \\
(0.012)\end{array}$ & $\begin{array}{c}0.082 * * * \\
(0.030)\end{array}$ & $\begin{array}{l}0.022 * \\
(0.012)\end{array}$ \\
\hline Primary Government Spending (first lag) & $\begin{array}{l}-0.061 \\
(0.108)\end{array}$ & $\begin{array}{c}0.015 \\
(0.041)\end{array}$ & $\begin{array}{l}-0.090 \\
(0.110)\end{array}$ & $\begin{array}{c}0.008 \\
(0.041)\end{array}$ \\
\hline Parliamentary Election & $\begin{array}{l}0.477 * \\
(0.257)\end{array}$ & $\begin{array}{c}0.07 \\
(0.089)\end{array}$ & & \\
\hline OGS if Output Gap >0 & & & $\begin{array}{c}0.587 * * \\
(0.283)\end{array}$ & $\begin{array}{c}0.373 * * * \\
(0.108)\end{array}$ \\
\hline OGS if Output Gap $<0$ & & & $\begin{array}{c}0.079 \\
(0.699)\end{array}$ & $\begin{array}{c}0.171 \\
(0.244)\end{array}$ \\
\hline$(O G S)^{*}($ Expenditure Rules Index $)$ if Output Gap $>0$ & & & $\begin{array}{l}-0.175 \\
(0.257)\end{array}$ & $\begin{array}{c}-0.138 * * \\
(0.062)\end{array}$ \\
\hline$(O G S) *($ Expenditure Rules Index) if Output Gap $<0$ & & & $\begin{array}{l}-0.576 \\
(0.447) \\
\end{array}$ & $\begin{array}{l}-0.014 \\
(0.175) \\
\end{array}$ \\
\hline Observations & 145 & 139 & 145 & 139 \\
\hline $\begin{array}{l}\text { Sargan/Hansen test of overidentifying restrictions ( } p \text { - } \\
\text { value) }\end{array}$ & 0.71 & $\begin{array}{r}0.97 \\
-\end{array}$ & 0.59 & 0.91 \\
\hline $\begin{array}{l}\text { Difference in Sargan/Hansen test for endogenous } \\
\text { regressor ( } p \text {-value) }\end{array}$ & 0.11 & 0.43 & 0.16 & 0.80 \\
\hline Kleinbergen-Paap rk Wald F-Statistic & 33.84 & 34.64 & 1.38 & 1.28 \\
\hline
\end{tabular}



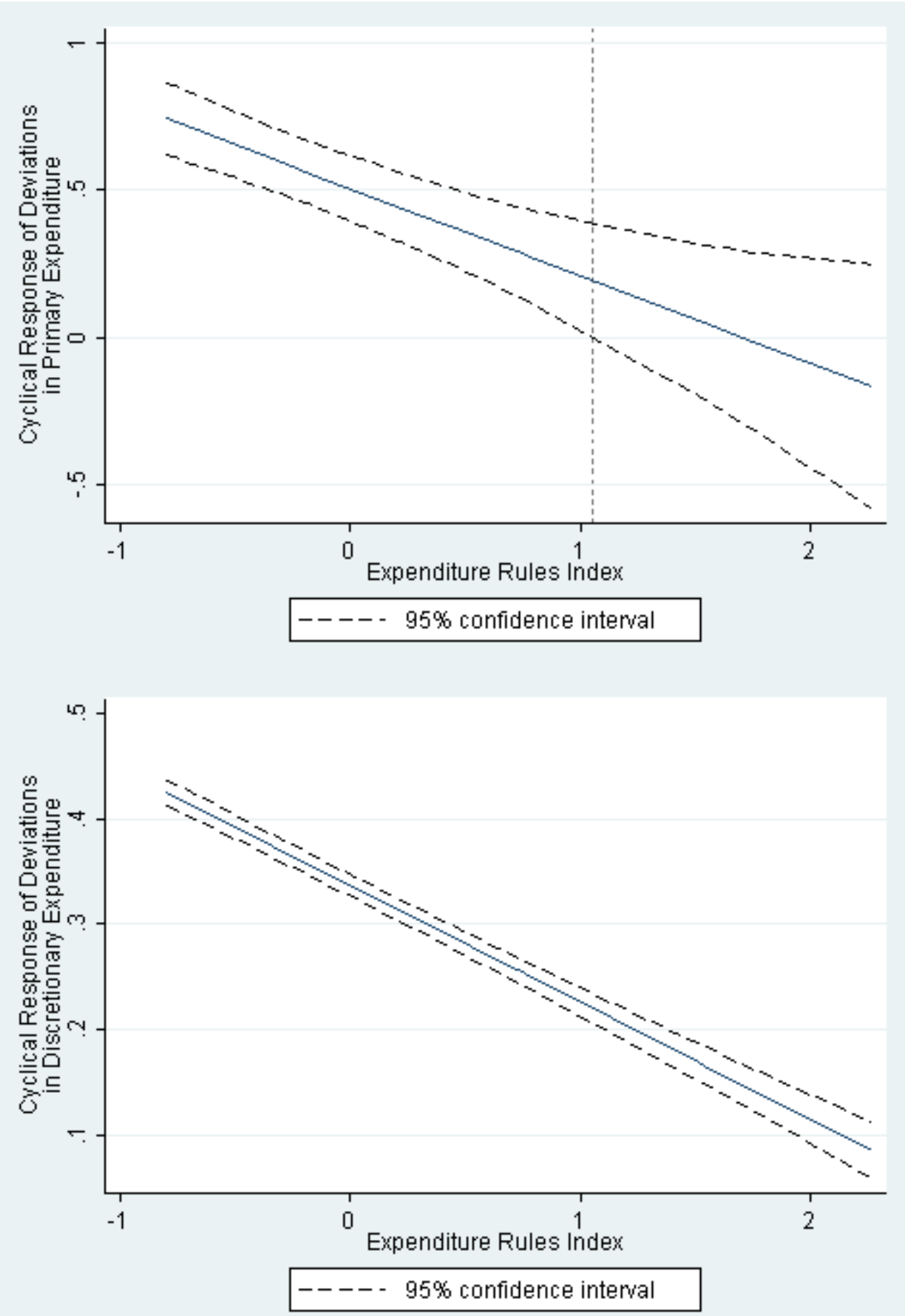

Figure 1: Overall cyclical response of spending deviations conditional on expenditure rules index

Note: Solid lines plot the overall response of expenditure deviations to output gap surprises ( $\partial \mathrm{dev} / \partial O G=\alpha+\beta E R$ ) against the expenditure rules index. The overall effect is significant at a $5 \%$ level if both boundaries of the $95 \%$ confidence interval are above or below the $\mathrm{x}$-axis. 